\title{
It is time for rural training in family medicine in Brazil!
}

Es hora de la capacitación rural en medicina familiar en Brasil!

\author{
Está na hora do treinamento em saúde rural para médicos de \\ família no Brasil!
}

Magda Moura Almeida ${ }^{a}$

Mayara Floss ${ }^{b}$

Leonardo Vieira Targac

John Wynn-Jones ${ }^{d}$

Alan Bruce Chater

a Universidade Federal do Ceará (UFC).

Fortaleza, CE, Brazil.

magda.almeida@ufc.br

(Corresponding author)

${ }^{b}$ Wonca Working Party on Rural Practice. mayarafloss@hotmail.com

c Universidade de Caxias do Sul (UCS). targalv@gmail.com

d Wonca Working Party on Rural Practice; European Rural and Isolated Practitioners Association (EURIPA).

john@johnwj.com

e Rural and Remote Medicine, University of Queensland. Australia.

bruce.chater@theodoremedical.com.au dos residentes rurais de baixa ron necessidades das áreas rurais no Brasil e os modelos de projeção para o provimento de força de trabalho de saúde nesses cenários.

Palavras-chave: Saúde da População Rural; Educação Médica; Medicina de Família e Comunidade.

\section{Resumen}

La brecha entre las necesidades de salud y la capacitación de los recursos humanos para la salud es mucho más evidente en las zonas rurales. En Brasil, un país de dimensiones continentales, estas diferencias se vuelven más desafiantes. La diversidad de las barreras geográficas y administrativas de acceso hace que los indicadores de salud de las poblaciones rurales y remotas sean peores que los de la población urbana. La Medicina Familiar podría abordar los determinantes sociales de la salud a través de la provisión de servicios humanos y desempeñar un papel importante en el estado de salud de los residentes rurales de bajos ingresos. Este ensayo es un llamado urgente para el debate sobre los modelos para proyectar el suministro de mano de obra de salud y los requisitos para las áreas rurales en Brasil.

Palabras clave: Salud Rural; Educación Médica; Medicina Familiar y Comunitaria.

Cite as: Almeida MM, Floss M, Targa LV, Wynn-Jones J, Chater AB. It is time for rural training in family medicine in Brazil! Rev Bras Med Fam Comunidade. 2018;13(40):1-4. http://dx.doi.org/10.5712/rbmfc13(40)1696

\section{Funding:}

none declared.

Ethical approval:

not necessary.

Conflict of interest

none declared.

Provenance and peer review:

peer reviewed.

Received: 02/22/2018.

Accepted: 02/23/2018. 
The United Nations Sustainable Development Goals aim precisely at removing inequalities and working towards universal health coverage. This implies that everyone should have a right to health and well-being, regardless of where they live. Almost half the world's population lives in rural areas. Besides that, only $23 \%$ of health workers are working in rural areas. ${ }^{1}$ Rural people deserve more equitable health services than this and while is everyone's problem governments and higher education institutions can work with these communities to become part of the solution.

"Rural" or "remote" does not have a universal accepted definition and should be broadly understood to include communities not commonly idealized as rural and not typically agricultural, such as migratory populations, island habitants, forest dwellers, fishing communities, African continental ancestry group, etc. ${ }^{2}$

In general, the perspective of those who live in big cities is that everywhere else is rural; however, those living in rural regional centers do not see their own community as rural. Strasser ${ }^{3}$ argues that concept of rural and remote is a matter of perception. However, we must recognize that the use of the "rural" term (as well as remote) could contribute to the insertion in projects at international level and stimulate the debate with other realities, since this is the international term adopted. Rural often means a different service need based on broadly skills of family doctors.

The Brazilian Institute of Geography and Statistics ${ }^{4}$ uses the binary classification to define the location of the domicile, categorized in urban or rural situation. In this context, just $16 \%$ of Brazilian population live in rural areas. However, $15 \%$ of the national population do not clearly fit into any of these categories alone. ${ }^{2}$

A large part of the Brazilian municipalities outside the large centers cannot offer their inhabitants a typically urban experience in terms of supply and access to services and products, whether public or private. This reinforces the hypothesis that the set of economic disadvantages, with numerous socio-environmental conflicts frequently occurring in areas of dispute between agribusiness and traditional rural communities, as well as tributary reasons, may explain partially interest in presenting a smaller proportion of the national territory as rural.

The prevalence of diseases and health conditions in Brazilian rural settings is more common. Accordingly to the National Health Survey, ${ }^{4}$ indicators of rural settings are always worse: more women have their first pregnancy under 20 years of age; many people who never attended dental care; women at the age of 50-69 without mammography; inadequate home sanitation and access to safe water, prevalence of people with visual impairment or some other disability, prevalence of current tobacco users. And since we cannot expect otherwise, a greater number of rural residents report, with self-assessment, their health as regular, poor and very poor. Thus, Brazilian rural population suffers from the inverse care law in which access to health care is lower for the population that needs it the most. ${ }^{5}$

A recent report by the International Labor Organization (ILO) has stated that the rural-urban divide is ubiquitous from the richest countries to the poorest countries, with $56 \%$ of those living in rural areas around the world not being covered by services of primary health care, which is the service model that they desperately need. ${ }^{6}$ In Brazil, only $6.2 \%$ of rural population has health insurance, therefore, mostly depending on public health services. ${ }^{4}$ Adequate access to quality health in rural settings is a form of social justice. 
The family physician should be able to resolutely handle and coordinate the care of most frequent health problems of the general population. In Brazil's rural areas, we deal with a huge territorial extension, difficult transportation and lack of trained human resources. The average number of 3,500 people by health staff is maintained regardless of the extension or geographical barriers.

Most of the physicians are trained in urban areas of big cities and require adaptation to the peculiarities of rural health services. This direction influences the future choice of workplace and work setting. ${ }^{7}$ According to an extensive international literature ${ }^{8}$ several factors contribute to increasing recruitment and retention of health professionals in rural areas. Three interventions at different times of medical training seem to be important. The first is the location of the school. The second deals with the exposure to rural health settings in undergraduate through clinical rotations with rural preceptorship and the third is fellowship in rural and family physician training programs.

The rural health professional must have a greater scope of competences to manage the wider range of health issues that will confront them as part of the daily work. The isolation and smaller numbers will result in smaller teams and restricted resources, making a broader scope of practice and generalist teamwork and interdisciplinary care even more important. ${ }^{2}$

A recent study with physicians linked to the "More Doctors Program" showed that physicians who worked in smaller cities (up to 10,000 inhabitants) or who were in primary care services distant more than 120 minutes from the headquarters of the health region performed a larger number of procedures and activities than the physicians who were in larger cities or closer to headquarters. ${ }^{9}$

The rights of people living in rural areas or belonging to ethnic-racial minorities have been constantly attacked, decreasing the power of claiming of these people. In order to close inequities between urban and rural settings, we need a rural workforce that is fit for the purpose. Medical students and young doctors in training can only understand the rural perspective and advocacy for its patients if significant rural placements are part of the standard undergraduate and graduate curricula. The increasingly specialized urban workforce is not a suitable model in rural areas where health professionals with a wider range of skills are needed.

It is time to work for rural family medicine to become a respected and recognized career. Rural inhabitants deserve the same access to and quality of health care and this involves ensuring that rural family physicians are well-educated, well-trained, and have had experiences that expose them to and prepare for work in rural practice. It is time to plan for rural health training in Brazil!

\section{References}

1. WHO. Increasing access to health workers in remote and rural areas through improved retention [Internet]. Vol. 23. Sciences, New York; 2010. Available from: http://www.who.int/entity/hrh/migration/hmr_expert_meeting_dolea.pdf

2. Targa L, Wynn-Jones J, Howe A, Anderson M, Lopes J, Lermen-Junior N, et al. Declaração de Gramado pela Saúde Rural nos países em desenvolvimento. Revista Brasileira de Medicina de Família e Comunidade [Internet]. 2014 Jul 30 [cited 2018 Feb 22];9(32):292-94. DOI: http://dx.doi.org/10.5712/rbmfc9(32)982

3. Strasser R. Rural health around the world: challenges and solutions [Internet]. Fam Pract. 2003 Aug 1;20(4):457-63. DOI: http://dx.doi. org/10.1093/fampra/cmg422

4. IBGE. Pesquisa Nacional de Saúde 2013 [Internet]. Instituto Brasileiro de Geografia e Estatística (IBGE). 2014; p. 181. Available from: ftp://ftp.ibge.gov.br/PNS/2013/pns2013.pdf 
5. Tudor Hart J. The Inverse Care Law. Lancet [Internet]. 2018 Feb 24;297(7696):405-12. DOI: http://dx.doi.org/10.1016/S0140$-6736(71) 92410-X$

6. Reid S, Worley P, Strasser R, Couper I, Rourke, J. 'What brings us together': The values and principles of rural medical education. In: Chater AB, Rourke J, Couper ID, Strasser RP, Reid S (eds.). WONCA Rural Medical Education Guidebook. World Organization of Family Doctors (WONCA): WONCA Working Party on Rural Practice, 2014 [accessed 2017 Jun 04]. Available from: www.globalfamilyldoctor.com

7. Howe A, Ives G. Does community-based experience alter career preference? New evidence from a prospective longitudinal cohort study of undergraduate medical students. Med Educ [Internet]. 2001 Apr 22 [cited 2018 Feb 25];35(4):391-97. DOI: http://dx.doi.org/10.1046/ j.1365-2923.2001.00866.x

8. Wilson NW, Couper ID, De Vries E, Reid S, Fish T, Marais BJ. A critical review of interventions to redress the inequitable distribution of healthcare professionals to rural and remote areas. Rural Remote Health. 2009;9(2):1060.

9. Girardi SN, Carvalho CL, Pierantoni CR, Costa J de O, Stralen AC de S van, Lauar TV, et al. Avaliação do escopo de prática de médicos participantes do Programa Mais Médicos e fatores associados. Ciênc saúde coletiva [Internet]. 2016;21(9):2739-48. DOI: http://dx.doi. org/10.1590/1413-81232015219.15912016 